\title{
Study of State of Mortuary at Tertiary Care Centre Mumbai
}

Dr. Mahendra Wankhede MD ${ }^{1 *}$, Dr. Feroz Ikbal Ph.D ${ }^{2}$, Dr. Harish Pathak MD ${ }^{3}$, Dr. Manoj B Parchake MD $^{4}$

\author{
${ }^{1}$ Associate Professor, Department of Forensic Medicine, Hindu Hruday Samrat Balasaheb Thackarey Medical College and R N Cooper \\ Hospital Vile Parle Mumbai 400056 India \\ ${ }^{2}$ Associate Professor Department of Centre of Hospital Management, Tata Institute of Social Science Mumbai-400088 India \\ ${ }^{3}$ Professor and Head, Department of Forensic Medicine, Seth Gordhandas Sunderdas Medical College \& King Edward Memorial \\ Hospital Parel Mumbai 400012 India \\ ${ }^{4}$ Associate Professor, Department of Forensic Medicine, Seth Gordhandas Sunderdas Medical College \& King Edward Memorial \\ Hospital Parel Mumbai 400012 India
}

DOI: $\underline{10.36347 / \text { sjams.2021.v09i04.020 }}$

| Received: 15.03.2021 | Accepted: 21.04.2021 | Published: 24.04.2021

*Corresponding author: Dr. Mahendra Wankhede

Abstract

Original Research Article

This article focuses on the state of mortuary, infrastructure and services provided by mortuary. As healthcare services are undergoing a rapid transformation so proper management and modernization of mortuary is essential. Covid 19 impact all over the world shows the importance of mortuary services. Data was collected from observation and secondary data taken from hospital like facility based factors and the staff working in tertiary care hospital in Mumbai. Data from infrastructure available at mortuary, facility available, staff working and risk and hazards to people working there along with situation in covid-19 pandemic. It was concluded that basic facilities are available but needs to modernization.

Keywords: Mortuary, healthcare services, Covid-19.

Copyright $(\odot 2021$ The Author(s): This is an open-access article distributed under the terms of the Creative Commons Attribution 4.0 International License (CC BY-NC 4.0) which permits unrestricted use, distribution, and reproduction in any medium for non-commercial use provided the original author and source are credited.

\section{INTRODUCTION}

India has achieved substantial life expectancy so survival level is increased. The current death rate for India in 2020 is 7.309 deaths per 1000 people, a $0.49 \%$ increase from 2019. So it is significant concern to holistically develop the mortuary. Overflow of bodies at mortuary so crucial to manage. Services offered at mortuary are storage, to conduct postmortem examination, to identify the unknown or unclaimed dead bodies, to remove dead bodies for burial or cremation purpose. The works done at mortuary are not only medico-legal but also some psychological aspects are related to it, which makes it very complex and delicate task [1].

As healthcare services are undergoing a rapid transformation so proper management and modernization of mortuary is essential. In recent times there is increasing need of high quality and standardized mortuary services which are sustainable in nature. As resources are limited so retention of highly qualified staff is key challenge to the administration. In the current competitive world society urge standard of healthcare services but services offered at mortuary are not satisfied ones. There is neglect from hospital management regarding mortuary infrastructure and services. Mortuaries having old infrastructure and unhygienic condition with rodents and foul smell creates problem for the society $[6,7]$.

Dead body management is very crucial task during mass disaster or pandemic period like recent Covid -19 periods. Proper dead body handling is very important for the safety of the doctors and staff working in mortuary. Strict infection control measures are to be implemented in mortuary. Mortuary is to be regularly disinfected and fumigated for minimizing the infections in mortuary premises.

\section{Material AND Methods}

Study was conducted in Seth GS Medical College and KEM Hospital during Jan 2020 to June 2020. Data was collected from observation and secondary data taken from hospital like facility based factors and the staff working there [8].

\section{Facility based factors}

1. Descriptive and exploratory- Physical- Dimensions, Architecture Services provided like refrigerators, electricity.

Manpower- Continue working doctors, Permanent/ temporary staff, Safety measures. 
Mahendra Wankhede et al; Sch J App Med Sci, Apr, 2021; 9(4): 588-592

2) Interventions of working staff and their condition and problems. Interventions of relatives of deceased regarding services provided at mortuary. (Qualitative). Data analysis was done by Microsoft excel.

\section{RESULTS}

According to table 1 State of mortuary structure, it shows that facility such as availability of entry and exit doors, post-mortem room, Record office, Pathologist office, Toilets for staff and visiting relatives, waiting room for relatives, Mortuary is accessible to different people and Sitting mortuary in basement unit were present in mortuary[9]. Also area is secure from entry at all times, presence of racks, the area is hidden from public viewing, the place provides easy access to vehicles for loading and unloading, presence of alarm bell, Presence of electricity and CCTV Camera were available in mortuary.

As per table no.2 Equipment and functionality of mortuary instruments in the Hospital, equipment such as personal protective equipment, post mortem tables, wheeled trolleys, stretchers, autopsy instruments, freezers, refrigerator and photographic camera were present.

According to presences of inputs for mortuary information management systems table no.3, all the necessary inputs were present except computer facility at mortuary.

As per Presence of drugs and supplies for mortuary services table no.4, availability of formalin, gloves, cotton and disinfectants, Gum boots, cotton, and body bags were present in Mortuary. Deodorizer and Stock cards were not available at mortuary [10].

Table no. 5 shows that number of dead bodies received in mortuary, highest number of dead bodies were received in month of May 787(25.38\%) followed by month of February 569(19.62) and least bodies were received in Month of April(427\%).

According to number of persons working in Mortuary table no.6, total 9 doctors were present out of which 7 are permanent. Among 13 mortuary attendant 8 were permanent working in mortuary. While 8 mortuary workers were permanent out of total 14 mortuary workers.

Table no.7 shows cold storage facility at KEM Hospital, cold storage mortuary cabinet (1) have capacity of storing 27 dead bodies. Cold storage cabinet (2) having capacity of storing 9 dead bodies.
As per table no. 8 shows Risks and Hazards in mortuary such as physical injuries like accidental injuries and musculoskeletal injuries. Sharp object injuries such as incised and cut injuries, infectious injures such as Aerosol-Mycobacterium Tuberculosis, Blood borne- HIV, Hepatitis B \& C and parasitic infections.

Table-1: State of mortuary structure in the KEM Hospital Indicators

\begin{tabular}{|l|l|}
\hline \multicolumn{2}{l}{ Hospital Indicators } \\
\hline Indicators & KEM Hospital Health Facility \\
\hline 1 & $\sqrt{ }$ \\
\hline 2 & $\sqrt{ }$ \\
\hline 3 & $\sqrt{ }$ \\
\hline 4 & $\mathrm{x}$ \\
\hline 5 & $\sqrt{ }$ \\
\hline 6 & $\sqrt{ }$ \\
\hline 7 & $\sqrt{ }$ \\
\hline 8 & $\mathrm{x}$ \\
\hline 9 & $\sqrt{ }$ \\
\hline 10 & $\sqrt{ }$ \\
\hline 11 & $\mathrm{x}$ \\
\hline 12 & $\mathrm{x}$ \\
\hline 13 & $\mathrm{x}$ \\
\hline 14 & $\sqrt{ }$ \\
\hline 15 & $\sqrt{ }$ \\
\hline 16 & $\sqrt{ }$ \\
\hline 17 & $\mathrm{x}$ \\
\hline 18 & $\sqrt{ }$ \\
\hline 19 & $\mathrm{x}$ \\
\hline 20 & $\mathrm{~V}$ \\
\hline 21 & \\
\hline 22 & \\
\hline & \\
\hline
\end{tabular}

1- Availability of mortuary, 2- Availability of entry and exit doors, 3- Mortuary has post-mortem room, 4-Suitable size mortuary room, 5-Record office, 6-Pathologist office, 7- Toilets for staff and visiting relatives, 8- Waiting room for relatives, 9- Mortuary is accessible to different people, 10- Sitting mortuary in basement unit, 11- Separate routes for entry by visiting relatives, medical staff, 12- Mortuary separate from other buildings, 19

13- Dignified surrounding of mortuary, 14Area is secure from entry at all times, 15- Presence of racks, 16- The area is hidden from public viewing, 17The area is large enough for moving the remains and adequately lit, 18- The place provides easy access to vehicles for loading and unloading, 19- The room has smooth, washable floor, 20-presence of alarm bell, 21Presence of electricity, 22- CCTV Cameras. ' $\sqrt{ }$ ' Indicator for assessing structure of the health facility
met by the Hospital
' $\mathrm{x}$ ' Indicator for assessing structure of the health facility
not met by the Hospital 
Mahendra Wankhede et al; Sch J App Med Sci, Apr, 2021; 9(4): 588-592

Table-2: Shows Equipment and functionality of mortuary instruments in the hospital.

\begin{tabular}{|l|l|}
\hline Indicator & KEM Hospital Health Facility \\
\hline 1 & $\sqrt{ }$ \\
\hline 2 & $\sqrt{ }$ \\
\hline 3 & $\sqrt{ }$ \\
\hline 4 & $\sqrt{ }$ \\
\hline 5 & $\sqrt{ }$ \\
\hline 6 & $\sqrt{ }$ \\
\hline 7 & $\sqrt{ }$ \\
\hline 8 & $\sqrt{ }$ \\
\hline 9 & $\mathrm{X}$ \\
\hline 10 & $\mathrm{X}$ \\
\hline 11 & $\sqrt{ }$ \\
\hline 12 & $\sqrt{ }$ \\
\hline 13 & $\mathrm{X}$ \\
\hline 14 & $\sqrt{ }$ \\
\hline
\end{tabular}

1-Personal protective equipment, 2- post mortem tables, 3- wheeled trolleys, 4- stretchers, 5autopsy instruments, 6- freezers, 7-refrigerator, 8photographic camera, 9- portable X-ray, 10-generator, 11-Thermometer, 12-Tape measure, 13-DNA machine, 14- weighing scale

' $\sqrt{ }$ 'Indicator for assessing presence and functionality of mortuary equipment of the health facility met by the Hospital

' $\mathrm{x}$ ' Indicator for assessing presence and functionality of mortuary equipment of the health facility not met by the Hospital.

Table-3: Presences of inputs for mortuary information management systems

\begin{tabular}{|l|l|}
\hline Indicator & KEM Hospital Health Facility \\
\hline 1 & $\mathrm{X}$ \\
\hline 2 & $\sqrt{ }$ \\
\hline 3 & $\sqrt{ }$ \\
\hline 4 & $\sqrt{ }$ \\
\hline 5 & $\sqrt{ }$ \\
\hline 6 & $\sqrt{ }$ \\
\hline 7 & $\sqrt{ }$ \\
\hline
\end{tabular}

\begin{tabular}{|l|l|}
\hline Indicator & KEM Hospital Health Facility \\
\hline 8 & $\sqrt{ }$ \\
\hline 9 & $\sqrt{ }$ \\
\hline 10 & $\sqrt{ }$ \\
\hline 11 & $\sqrt{ }$ \\
\hline 12 & $\sqrt{ }$ \\
\hline
\end{tabular}

1-Presence of a computer, 2- mortuary register, 3-records for corpse release, 4-record for received corpses, 5-death certificate copies, 6-recording book for items found with the dead, 7-autopsy form, 8-records for medical records of deceased, 9-body tags,10-box files, 11-temperature monitoring chart,12-telephone

$\sqrt{ }$ - Indicator for assessing presence and functionality of mortuary equipment of the health facility met by the Hospital

x- Indicator for assessing presence and functionality of mortuary equipment of the health facility not met by the Hospital

Table-4: Presence of drugs and supplies for mortuary services

\begin{tabular}{|l|l|}
\hline Indicator & KEM Hospital Health Facility \\
\hline 1 & $\sqrt{ }$ \\
\hline 2 & $\sqrt{ }$ \\
\hline 3 & $\sqrt{ }$ \\
\hline 4 & $\mathrm{x}$ \\
\hline 5 & $\mathrm{x}$ \\
\hline
\end{tabular}

1-Availability of Formalin, 2-Gloves, cotton and disinfectants, 3-Gum boots, cotton, and body bags, 4-Deodorizer, 5-Stock cards.

$\sqrt{ }$ - Indicator for assessing presence of drugs and supplies required in the mortuary met by the hospital.

x- Indicator for assessing presence drugs and supplies required in the mortuary not met by the hospital.

Table-5: Number of dead bodies received in mortuary

\begin{tabular}{|l|l|l|}
\hline Month & $\begin{array}{l}\text { Number of dead bodies received in } \\
\text { mortuary }\end{array}$ & $\begin{array}{l}\text { Average number of dead } \\
\text { bodies received per day }\end{array}$ \\
\hline January & 562 & 18.12 \\
\hline February & 569 & 19.62 \\
\hline March & 530 & 17.09 \\
\hline April & 427 & 14.23 \\
\hline May & 787 & 25.38 \\
\hline June & 561 & 18.7 \\
\hline
\end{tabular}


Table=6: Number of persons working in mortuary

\begin{tabular}{|c|c|c|c|c|}
\hline Staff & Total & Permanent & Temporary & Duty Hours \\
\hline Doctors & 9 & 7 & 2 & 9AM to 9PM \\
\hline Mortuary attendants & 13 & 8 & 5 & $\begin{array}{l}\text { Three shifts- } \\
\text { 7AM to 3PM } \\
\text { 3PM to } 11 \mathrm{PM} \\
11 \mathrm{PM} \text { to } 7 \mathrm{AM}\end{array}$ \\
\hline Mortuary workers & 14 & 8 & 6 & $\begin{array}{l}\text { Three shifts- } \\
\text { 7AM to 3PM } \\
\text { 3PMto 11PM } \\
\text { 11PM to 7AM }\end{array}$ \\
\hline
\end{tabular}

Table-7: Cold storage facility at KEM Hospital

\begin{tabular}{|l|l|}
\hline Mortuary Cold cabinet & Dead Body Capacity \\
\hline 1st Cold storage & 27 \\
\hline 2nd Cold storage & 9 \\
\hline Total & 36 \\
\hline
\end{tabular}

Table-8: Risks and Hazards in mortuary

\begin{tabular}{|l|l|}
\hline Risk category & Risks \\
\hline Physical Risks & $\begin{array}{l}\text { Accidental injuries } \\
\text { Musculoskeletal injuries }\end{array}$ \\
\hline Sharp object injuries & Incised and cut injuries \\
\hline Infectious Diseases & $\begin{array}{l}\text { Aerosol-Mycobacterium Tuberculosis } \\
\text { Blood borne- HIV, Hepatitis B \& C and parasitic infections }\end{array}$ \\
\hline
\end{tabular}

\section{DISCUSSION}

Healthcare system changes more rapidly nowadays and intended for the holistic development of the society. Patients are expected the standard level of health facility from every department of health services. Mortuary services of the healthcare system are expected to be equally global standard level and up to the satisfaction level of the relatives of the deceased.

Basant lal sirohiwal et al. [2] describe the design and layout of mortuary complex in detail. As per this article most of the facilities are present, some present but not of standard level and some are absent at KEM Hospital mortuary. Veranda and autopsy surgeon room present but computer facility is not available in the mortuary. Toilets and bathrooms for the staff are available. Separate investigation officers room and separate store room is absent.

In KEM Hospital Mortuary complex there is separate room for infectious bodies and decomposed bodies is available but waiting room and doctors changing room are not present. Floor and walls are not suitable for cleaning purpose and floors are damaged due to problems of rodents. No X-ray machine facility available at mortuary. Before autopsy room there is pre autopsy room for receiving and handing of dead bodies to the relatives.

Autopsy room has the adequate space of size $24 \times 16$ square feet size having 3 central platforms of size $4 \times 8$ square feet for conducting the postmortem examinations as per the guidelines. Windows, proper vent and duct system for exit of foul smelling gases are present. Mortuary tables are to be made of stainless steel with proper drainage system but mortuary tables in KEM Hospital are locally cement made with attached drainage system.

Abhishek et al. [5] also explained the basic infrastructure human resources management in mortuary. They lay importance to the scientific infrastructure for the minimum health risks to the staff and doctors working in mortuary and for proper infection control.

James Kazunga et al. [3] also explained the state of mortuary and mortuary services. The findings of mortuary infrastructure and services at KEM Hospital mortuary are mostly similar to this study. The basic infrastructure and equipments are available at KEM Hospital mortuary. The drugs and other essential supplies are to be received in mortuary regularly [7].

The commonly occurred occupational hazards at KEM mortuary are accidental injuries, musculoskeletal injuries during handling of dead bodies. Incised and cut injuries due to sharp instruments are also common. The blood-borne and air -borne infections are also common in mortuary like mycobacterium tuberculosis infection. These findings are similar with study of Sunil kadam et al. [4] autopsy practices potential source of occupational hazards. To prevent these blood-borne infections regular vaccination in every 6 months is given to the mortuary staff. The 
Mahendra Wankhede et al; Sch J App Med Sci, Apr, 2021; 9(4): 588-592

proper ventilation and supply of N-95 masks are essential to prevent airborne infections.

The staffs working in KEM Mortuary is adequate to the current workload. The duties of the staff are divided in three shifts due to continuous working of mortuary for 24 hours. The workload of mortuary is estimated on basis of number of dead bodies received per month. The number of dead bodies received in mortuary is approximately 550 bodies per month. In may 2020 , bodies received in mortuary are 787 , due to ongoing covid -19 pandemic.

The cold storage capacity of KEM Hospital mortuary is up to 36 bodies. This storage capacity is very less as compared to the bodies received in mortuary. So during any mass disaster event or in recent ongoing Covid-19 pandemic period, there is difficulty for storage of dead bodies in mortuary and creates hurdle for dead body management in these crucial periods.

\section{Conclusion}

The basic infrastructure facilities are available in KEM Hospital mortuary and need to be upgraded. Cold storage capacity is not adequate as compared to the number of dead bodies received in mortuary. Other services like equipment and functionality of mortuary instruments, mortuary information management systems, presence of drugs and supplies for mortuary services are according to the standard guidelines. Human resource management is adequate according to the work load.

\section{REFERENCES}

1. Bonds L, Gaido L, Woods J, Cohn D, Wilson ML. Infectious diseases detected at autopsy among patients at an urban public hospital: 1996-2001. Am J ClinPathol.2003; 119: 866-72

2. Sirohiwal BL, Paliwal PK, Sharma L, Chawla H. Design and layout of mortuary complex for a medical college and peripheral hospitals. J Forensic Res. 2011;2:102e.

3. Kazungu J, Nanyingi M, Katongole SP, Anguyo RD, Wampande LN. The State of Mortuary and Mortuary Services in Public Health Facilities of South Western Uganda.

4. Kadam SS, Akhade S, Desouza K. Autopsy practice, potential sources of occupational hazards: A review for safety and prevention. Journal of Indian Academy of Forensic Medicine. 2015;37(2):196-201.f

5. Abhishek Yadav, Kulbhushan, Antara debbarma. Establishment of postmortem center mortuary-ii. Manpower and human resource management. RFP journal of hospital administration.2019;3(1):15-19.

6. National Health Services (NHS) Scotland, Scottish Health Planning Note 20Facilities for Mortuary and Postmortem Room Services Design and briefing guidance, (2002), available on http://www.hfs.scot.nhs.uk/publications/shpn-20v1.pdf. 26/02/2014.

7. Infrastructure Unit Support Systems (IUSS), iuss health facility guides Hospital Mortuary Services. 2014, Republic of South Africa. Available on http://www.iussonline.co.za/iuss/wpcontent/upload s/2013/03/2014_03_19-IUSS-Hospital- MortuaryServices-proposal.pdf [accessed on 11/10/2014].

8. Patwary MA, Sarker MH. Quantitative assessment of mortuary waste: occupational safety and environmental health. Journal of Hospital Administration. 2012 Sep;1(1):49.

9. Hin Ma H, Chan GS, Tsang GK. Hospital care during the end-of-life journey: a survey of next of kin in the mortuary of a public hospital in Hong Kong.

10. Rathinam RD, Chopra M, Singh A, Bhardwaj A, Mithra P, Siddique A. Perceptions of relatives toward medico-legal investigation and forensic autopsy: A cross-sectional survey from rural Haryana. Journal of Medical Society. 2013 Sep $1 ; 27(3): 173$. 